\title{
Studies on vitamin D metabolism in malnourished children
}

\author{
BY N. RAGHURAMULU AND VINODINI REDDY \\ National Institute of Nutrition, Indian Council of Medical Research, \\ Jamai Osmania (PO), Hyderabad-500 007, A P, India
}

(Received 16 February 1981 - Accepted 11 November 1981)

1. Basal levels of serum 25-hydroxy vitamin $\mathrm{D}$ (25-OHD) were estimated in ten normal children and twenty-seven children with protein-energy malnutrition.

2. Five normal children and fourteen malnourished children were administered a single massive dose of $15 \mathrm{mg}$ vitamin D orally and the remaining children received oral supplements of $50 \mu \mathrm{g}$ vitamin D daily for $20 \mathrm{~d}$. Blood samples were obtained after 10 and $20 \mathrm{~d}$ of dosing and serum 25-OHD levels were repeated.

3. The basal serum 25 -OHD levels were significantly lower $(P<0.05)$ in malnourished children than in normal children.

4. Administration of a single massive dose of vitamin $D$ as well as daily supplementation of small doses resulted in significant increases in serum 25-OHD levels within $10 \mathrm{~d}$. However, the increase with a massive dose was of a higher magnitude. There was no significant difference between the normal and malnourished children.

5. The binding capacity of serum to 25-OHD was similar in both the groups.

6. These results suggest that vitamin $\mathbf{D}$ metabolism is not altered in protein-energy malnutrition.

Vitamin D deficiency rickets is not uncommon in children with protein-energy malnutrition (PEM). In fact, the incidence of rickets has been reported to be higher in malnourished children than in normal children (Pramanik et al. 1971; Machanda \& Lai, 1972). It is not clear whether these two conditions merely co-exist because of poverty and poor living conditions or whether malnutrition is causally related to rickets. Attempts were, therefore, made to evaluate the possible inter-relationship between these two deficiency diseases.

Serum 25-hydroxy vitamin D (25-OHD) is now recognized as a sensitive indicator of vitamin D status. Our earlier studies have shown that serum 25-OHD levels were significantly lower in malnourished children as compared to well-nourished children (Raghuramulu \& Reddy, 1980) suggesting that there may be a defective conversion of vitamin $\mathrm{D}$ to its active metabolite. In the present study, we have examined the serum $25-\mathrm{OHD}$ response to oral administration of vitamin D. The capacity of serum to bind 25-OHD was also determined in normal and malnourished children.

\section{SUBJECTS AND METHODS}

Ten normal children and twenty-seven malnourished children aged between 1 and 5 years were investigated. Normal children had weights exceeding $80 \%$ of the local standard (Rao et al. 1976) whereas malnourished children had weights below $60 \%$ of the standard. Serum albumin concentration ranged from $35-40 \mathrm{~g} / \mathrm{l}$ in normal children while the levels were below $30 \mathrm{~g} / \mathrm{l}$ in malnourished children. None of them received vitamin D before the study. Fasting blood samples were analysed for serum phosphorus (Chen et al. 1956) and alkaline phosphatase (EC 3.1.3.1; Bodansky, 1933). Serum calcium was determined by atomic absorption spectrophotometer. Total protein was estimated by the method of Lowry et al. (1951). Serum 25-OHD was measured by the competitive protein binding assay (Belsey et al. 1974). The binding capacity of serum to 25-OHD was determined by incubating $10 \mu \mathrm{l}$ diluted serum (diluted 200 times with deionised water) and 3500 counts $/$ min of ${ }^{3} \mathrm{H}$-labelled 25-hydroxy vitamin $\mathrm{D}_{3}\left[25-\mathrm{OH}\left({ }^{3} \mathrm{H}\right) \mathrm{D}_{3}\right]$ for $2 \mathrm{~h}$ at $4^{\circ}$. The bound and free fractions were separated using dextran-coated charcoal.

Five normal children and fourteen malnourished children were administered a single 
Table 1. Serum biochemical measurements in children

\begin{tabular}{|c|c|c|c|c|}
\hline & \multicolumn{2}{|c|}{$\begin{array}{l}\text { Normal } \\
\text { children (10) }\end{array}$} & \multicolumn{2}{|c|}{$\begin{array}{l}\text { Malnourished } \\
\text { children (27) }\end{array}$} \\
\hline & Mean & SE & Mean & $\mathrm{SE}$ \\
\hline Calcium (mg/l) & 89.0 & 2.9 & 87.0 & $4 \cdot 2$ \\
\hline Phosphorus (mg/l) & $62 \cdot 0$ & $5 \cdot 0$ & $45 \cdot 0^{* *}$ & $2 \cdot 6$ \\
\hline $\begin{array}{l}\text { Alkaline phosphatase } \\
\text { (EC 3.1.3.1) BU† }\end{array}$ & $5 \cdot 6$ & $0 \cdot 8$ & $5 \cdot 1$ & 0.6 \\
\hline $25-\mathrm{OH} \mathrm{D} \mathrm{D}_{3} \mathrm{ng} / \mathrm{ml}$ & $35 \cdot 2$ & $4 \cdot 8$ & $18 \cdot 3^{*}$ & $4 \cdot 5$ \\
\hline $\begin{array}{l}\text { Serum-binding capacity: } \\
\text { pmol } 25-\mathrm{OH} \mathrm{D}_{3} \text { bound } / \mathrm{mg} \\
\text { serum protein }\end{array}$ & 0.23 & 0.01 & $0 \cdot 22$ & $0 \cdot 11$ \\
\hline $\begin{array}{l}\text { nmol 25-OH } D_{3} \text { bound } / 1 \\
\text { serum }\end{array}$ & 17.8 & $0 \cdot 7$ & $16 \cdot 5$ & $0 \cdot 4$ \\
\hline
\end{tabular}

Values in parentheses indicate number of subjects.

25-OH $\mathrm{D}_{3}, 25$-hydroxy vitamin $\mathrm{D}_{3}$.

* $P<0.05, * * P<0.01$.

$\dagger \mathrm{mg} P$ liberated $/ \mathrm{h}$ per $100 \mathrm{ml}$ serum at $37^{\circ}$.

massive dose of $15 \mathrm{mg}$ vitamin $\mathrm{D}_{3}$ orally and the remaining children of both groups received small oral supplements of $50 \mu \mathrm{g}$ vitamin $\mathrm{D}_{3}$ daily for $20 \mathrm{~d}$. Blood samples were obtained after 10 and $20 \mathrm{~d}$ of dosing and serum 25-OHD levels were repeated. Informed consent was obtained from the parents and the study was approved by our ethical committee since both schedules of vitamin D supplementation were being used for treatment and prevention of rickets in young children.

Pure crystalline vitamin $\mathrm{D}_{3}$ was obtained from the Sigma Chemical Company, USA and checked for its purity spectrophotometrically. Vitamin $\mathrm{D}_{3}$ was dissolved in $95 \%$ ethanol and made up to appropriate volumes with refined peanut oil.

\section{RESULTS}

Student's $t$ test was used for statistical analysis of the results. Serum Ca and alkaline phosphatase levels were not different in normal and malnourished children. Serum $P$ levels were, however, significantly lower $(P<0 \cdot 01)$ in malnourished children.

Initial levels of serum 25-OHD ranged from $15-45 \mathrm{ng} / \mathrm{ml}$ in normal children while in malnourished children the levels were significantly lower $(P<0.05)$ (Table 1$)$. The capacity of serum to bind 25-OHD, expressed per mg protein or per 1 serum, was similar in normal and malnourished children.

Following the massive dose of vitamin $\mathrm{D}$, there was a significant increase in 25-OHD levels on the tenth day and they showed a declining trend to $20 \mathrm{~d}$ (Fig. 1). The mean increase was slightly higher in normal than in malnourished children but this difference was not significant. Daily supplements of small doses of vitamin D also resulted in a significant increase in serum 25-OHD levels within $10 \mathrm{~d}$ in both groups. However, the magnitude of increase was not as high as that obtained with a massive dose. The levels reached a plateau by $20 \mathrm{~d}$, though the supplementation was continued. In normal children, the values were slightly higher at $20 \mathrm{~d}$ than at $10 \mathrm{~d}$ but they were not statistically different.

In the present study normal levels of serum 25-OHD ranged from $15-45 \mathrm{ng} / \mathrm{ml}$, which are higher than those reported for normal subjects in the UK (Stamp, 1975; Poskitt et al. 1979). 


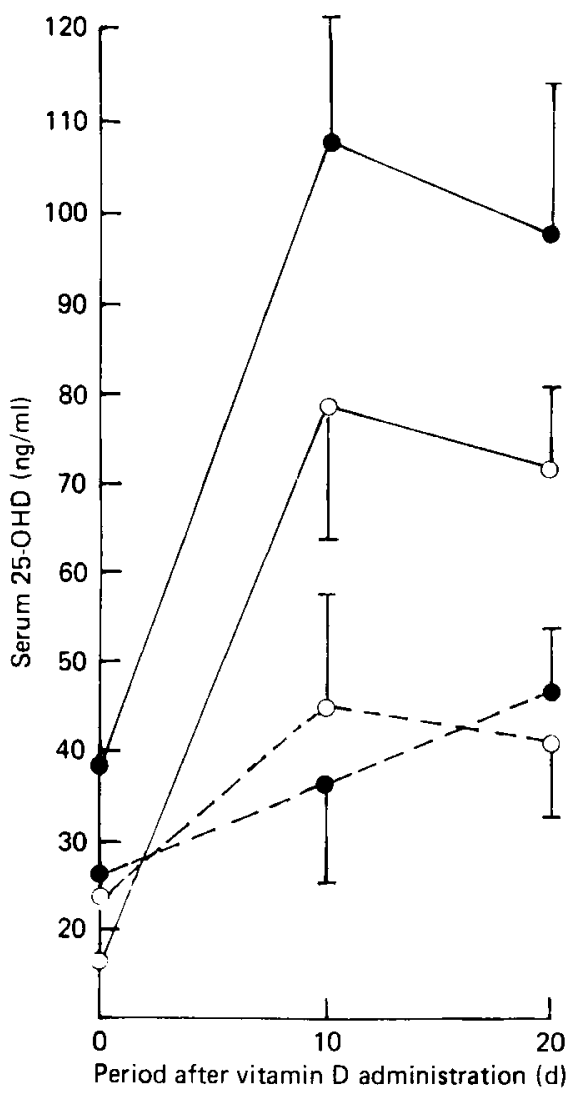

Fig. 1. Serum 25-hydroxy vitamin D (25-OHD) levels in response to oral administration of daily supplements of $50 \mu \mathrm{g} \mathrm{(--)}$ ) and single massive dose of $15 \mathrm{mg}(-)$ of vitamin D in five normal (O) and fourteen malnourished $(O)$ Indian children. Values are means with their standard errors represented by vertical bars.

This may probably be due to the differences in exposure to sunlight. Malnourished children living in the same environment showed significantly lower levels of 25-OHD confirming our earlier observations (Raghuramulu \& Reddy, 1980).

Vitamin $D$ is a prohormone which becomes active on transformation to its hydroxylated derivatives. The increase in serum 25-OHD has been used as an index of response to various forms of vitamin D treatment. Whyte et al. (1979) reported that when normal subjects were given a single massive dose of vitamin $\mathrm{D}$, there was a rapid increase in serum 25-OHD reaching a peak level after one week. However, the increase was not sustained. The normal children studied here showed a similar response to massive vitamin $\mathrm{D}$ administration, but the serum 25-OHD levels were much higher. We found a threefold increase above the basal value for 25-OHD. This may have been due to the relatively larger dose of vitamin $\mathrm{D}$ used in the present study.

Changes in plasma 25-OHD during daily supplementation of vitamin D have also been reported. Stamp et al. (1977) found that when their subjects were given $1 \mathrm{mg}$ vitamin D daily, plasma 25-OHD increased steadily, but with smaller doses ranging from 50-250 $\mu \mathrm{g}$ a plateau concentration was reached after 3 weeks. In the present study, normal children recieving $50 \mu \mathrm{g}$ vitamin $\mathrm{D}$ showed a similar response but the $25-\mathrm{OHD}$ levels were much higher. Basal levels of $25-\mathrm{OHD}$, which represent endogenous synthesis, were equivalent to 
those achieved in Western subjects by daily doses of $250 \mu \mathrm{g}$. These values suggest that a considerable amount of vitamin $\mathrm{D}$ is obtained by exposure to sunlight.

Liver is the major site of 25 hydroxylation of vitamin D and this has been shown to be impaired in patients with liver diseases (Avioli \& Haddad, 1973). It has been suggested that vitamin D metabolism may also be altered in children with PEM due to hepatic changes. However, the results obtained in the present study indicated that the response to vitamin $\mathrm{D}$ was normal in malnourished children. Though the initial levels were low, the rise in 25-OHD following vitamin D administration was similar to that seen in normal subjects. These results indicate that there is no defect in the conversion of vitamin $D$ to its active metabolite.

Plasma 25-OHD is bound to a specific serum globular protein which is essential for its transport to the kidney where it is further hydroxylated to 1,25 -dihydroxy vitamin $D_{3}$. Alteration in the concentration of the binding protein can modify the levels of 25-OHD. Imawari et al. (1979) reported that the levels of the binding protein are significantly reduced in patients with liver diseases and that they correlate well with serum albumin. The concentration of this protein may be expected to be decreased in protein deficiency. However, the results of the present study indicate that the binding capacity of serum to 25-OHD is not altered in malnourished children though serum albumin levels are reduced. This would suggest that there is a preferential synthesis of the carrier protein.

These studies indicate that vitamin D metabolism is not altered in PEM. Children of the poor communities depend entirely on sunshine for their vitamin $\mathrm{D}$ as they get very little from their diets. It is possible that malnourished children, being less active, may not be exposed to sunlight to the same extent as normal children. Further studies are needed to determine the factors that contribute to the prevalance of rickets in poor communities.

\section{REFERENCES}

Avioli, L. V. \& Haddad, J. G. (1973). Metabolism 12, 507.

Belsey, R. E., Deluca, H. F. \& Potts, J. T. Jr (1974). J. clin. Endocr. Metab. 38, 1046.

Bodansky, A. (1933). J. biol. Chem. 101, 93.

Chen, P. S. Jr, Toribara, T. Y. \& Warner, H. (1956). Analyt. Chem. 28, 1756.

Imawari, M., Akanuma, Y., Itakura, H., Muto, Y., Kosaka, K. \& Goodman, D. S. (1979). J. Lab. clin. Med. 93, 171.

Lowry, D. A., Rosebrough, N. J., Farr, A. L. \& Randall, R. J. (1951). J. biol. Chem. 193, 265.

Manchanda, S. S. \& Lai, H. (1972). Ind. J. Pediat. 39, 52.

Poskitt, E. M. E., Cole, T. J. \& Lawson, D. E. M. (1979). Br. Med. J. 1, 221.

Pramanik, A. K., Gupta, S. \& Agarwal, P. S. (1971). Ind. Pediat. 8, 95.

Raghuramulu, N. \& Reddy, V. (1980). Archs Dis. Childh. 55, 285.

Rao, D. H., Satyanarayana, K. \& Gowrinath Sastry, J. (1976). Ind. J. Med. Res. 64, 629.

Stamp, T. C. B. (1975). Proc. Nutr. Soc. 34, 119.

Stamp, T. C. B., Haddad, J. G. \& Twigg, C. A. (1977). Lancet i, 1341.

Whyte, M. P., Haddad, J. G. Jr, Walters, D. D. \& Stamp, T. C. B. (1979). J. clin. Endocr. Metab. $48,906$. 